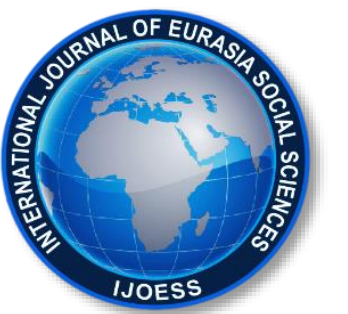

International Journal of Eurasia Social Sciences

Vol: 10, Issue: 37, pp. (783-808).

Research Article

Received: 06.06.2019 Accepted: 23.09.2019

\title{
A STUDY FOR BUSINESS INTERNAL ENVIRONMENT TURBULENCE MANAGEMENT
}

\author{
Kıvanç KÖMÜRCü \\ Doktora Öğrencisi, Kırıkkale Üniversitesi, komurcu.kivanc@gmail.com \\ ORCID: https://orcid.org/0000-0003-4811-5061 \\ Ismail GÖKDENIZ \\ Assoc. Prof. Dr., Kırıkkale Üniversitesi, isgokdeniz@gmail.com \\ ORCID: https://orcid.org/0000-0003-4342-0200
}

\begin{abstract}
The aim of this study is to create and analyze a Turbulence Management Model for the internal environment of a business. In this study, the Analytic Hierarchy Process has been used. In the first phase of the study, model is created. In the turbulence model, the weights of the turbulence characteristics, the weights of the internal environment factors, the weights of the management functions are calculated with the Analytic Hierarchy Process. According to the results of the study, in internal environment, the weights of creating turbulence of the characteristics complexity, changeability, predictability which are in model recommended can be identified. The second result is that it has been determined that each internal environment factor is important in what degree according to turbulence characteristics. Another result is that the priorities of the management functions can be calculated according to each internal environment factor. Consequently; for business within the research, it is determined that coordinating function is important at first in turbulence management. Secondly important management function is controlling. It is determined that these two management functions are respectively followed by directing, planning and organizing functions. The results of the study give information about which business requires giving priority what management functions.
\end{abstract}

Keywords: Turbulence Management, Analytic Hierarchy Process, Turbulence Model 


\section{INTRODUCTION}

The sectoral and macro environment which constitutes external environment of a business affects the routine actions of the business, its performance and long-termed goals (Bourgeoıs, 1985). From this aspect, external environment is a basic parameter that affects the business strategically (Mason, 2007). On the other hand, internal environment which is comparatively under control the business in regard to external environment(Koçel, 2018) is not only significant from the point of actualizing the functions and actions of the business, but also affecting the strategic targets of the business. The internal and external environment of the business that is operationally and strategically important can be exposed to environmental characteristics which is not homogeneous and stable in spite of various reasons (lansiti, 1995; Kuivalainen, Sundqvist, Puumalainen \& Cadogan, 2004; Mason, 2007; Papulo and Papulova, 2010). One of such special conditions is also turbulence environment.

Turbulence is a hostile situation that threatens the survival and the growth of organizations (Smart and Vertinsky 1984). In studies which are conducted, it is realized that turbulence has influenced negatively the performance of the organization (Power and Reid, 2005; Boyne and Meier, 2009). Turbulence, as a phenomenon, is defined as dynamism in organizational environment which includes the rapid, unexpected change in environmental sub dimensions of the organization (Mason, 2007). Turbulence is usually seen as major challenge with which organizations encounter. Turbulence is a condition which arises if an organization encounters with nontrivial, rapid and discontinuous changes. In literature, some authors are used in the same meaning turbulence and uncertainty, however; the case is not in this way. Turbulence usually causes uncertainty. Therefore; uncertainty, rather than synonymy, is thought as an outcome of turbulence. Hence, studies have shown that turbulence is the best predictor of the environmental uncertainty perceived (Cameron, Kim,\& Whetten, 1987). In literature, there are different classifications (Dess and Beard, 1984; Rosca and Moldoveanu, 2009) related to turbulence constituents as well as, Dess and Beard (1984) have explained turbulence with aspects of munificence, complexity and dynamism. Rosca and Moldoveanu (2009) defines turbulence as a condition which is the function of the changeability and predictability factors. The changeability phenomenon is explicated as the complexity of the environment and the function of new organization challenges to which the organization is exposed. On the other hand, predictability is stated as a notion that includes the speed of changeability and the future visibility of the decision-making period.

In literature review, it has been seen that studies mentioned about various arguments are made for maintaining uninterruptedly business actions in the turbulence conditions(Cameron, Kim,\& Whetten, 1987; Iansiti, 1995; Rosca and Moldoveanu, 2009; Melton, 2017).In a research which has been made, it has been determined that centralization, conservativeness, conflict, rigidity, secrecy, scapegoating of leaders have increased. On the contrary, it has been determined that knowledge sharing, participation, long-term planning, morale, innovativeness and credibility of leaders have decreased. Rosca and Moldoveanu (2009) has emphasized that the flexibility of organization and management, the extraversion and strategic system in 
environments with turbulence are developed in terms of management's general requirements. Melton (2017) studied in public organizations, with reference to the idea related to how turbulence affects managerial strategy. In the study, it has been investigated how managerial strategy changes toward external environment and that managers combat with turbulence. Boyne and Meier (2009), in their study, investigated the relation between structural stability and performance with turbulence in public organizations. In another study, it has been investigated the effect of environmental turbulence on international performance (Kuivalainen, Sundqvist, Puumalainen, Cadogan, 2004). In another study, it has been investigated appropriate organizational designs for turbulence (Siggelkow and Rivkin, 2005). lansiti(1995), in environments with turbulence, has investigated the role of the performance of product development on achieving and overcoming difficult conditions which are encountered.

When it is analyzed studies in literature, it has been seen that turbulence condition, from the point of business, is usually scrutinized and investigated in the context of external environment (lansiti, 1995; Rosca and Moldoveanu, 2009;Kuivalainen, Sundqvist, Puumalainen, \&Cadogan, 2004). However; it is not possible to be thought in terms of only external environment dynamics, the encounter of a business and turbulence. It can be said that the factors causing turbulence in external environment where business has functioned can be more in terms of intensity. In addition, the degree of turbulence which business encounters in its external environment can be more critical for affecting business actions. Nevertheless, business, also in terms of internal environment, can encounter with turbulence. In other words, turbulence can occur because of reasons which arises from the organizational structure and process of business. Therefore; business requires maintaining its actions if business encounters with potential turbulence. In an internal environment with turbulence, that business maintains its actions depends on the opportunities and capabilities which business has. However; in an internal environment with turbulence, various factors are determinant on which business maintains its actions, as well as it is fundamental that the problem's management size is. In other words, various sources and capabilities which business has in an environment are important, but; sources and capabilities which business has are manageable, and it can be said this is a basic ability that is ultimately expected. Business requires managing its actions under homogeneous and unusual conditions with which business encounters in turbulence environment.

If turbulence condition in a business is considered in terms of management phenomenon, it requires data and information related to unusual circumstances and conditions which is due to the nature of turbulence. This can be met with being analyzed in detail the internal environment of business. The first of subjects that needs to be determined about analyzing business internal environment is characteristics that creates turbulence in internal environment. In literature review, various characteristics which creates turbulence have been analyzed in detail and researched (Rosca and Moldoveanu, 2009). The sector which business has functioned or turbulence characteristics which is special to the structure and process of business can show variety and difference. Therefore; the problem can be understood by determining the characteristics which define turbulence and occurs in the internal environment of business. This is why; knowing the characteristics which causes 
turbulence in the internal environment of business is necessary in terms of which characteristics need to be considered in turbulence management. On the other hand; the degree of effect which turbulence characteristics can create in internal environment of business can differ. For instance; the effect which changeability factor can create in internal environment of business or the effect of predictability factor in internal environment of business can be different. For this reason, in turbulence management, knowing each turbulence characteristic's significance level in internal environment is a necessary information for turbulence management.

Another subject which needs to be known in turbulence management is that the limits and scope of internal environment related to turbulence is defined. Because, the internal environment of business expresses the plane in which the functions and actions of business are actualized. The determination of the factors which constitute the internal environment of business is significant because it gives information related to what business' functions and actions which are affected or will be affected by turbulence are. Another subject is that the response and significance level of the factors which constitute the internal environment of business can be different against the turbulence characteristics. For instance; human resources system can be different if supply function which is one of the business' functions is affected by predictability factor. Consequently; knowing each business internal environment factor's response degree against the turbulence characteristics is necessary for turbulence management.

In turbulence management, another subject which needs to be considered is to analyze the management action in detail according to the turbulence characteristics with which are encountered in the internal environment of business and business environment factors. In turbulence environment, business management' actions can differ according to business' functions. For instance; the priorities of management' functions of business' financing function and the priorities of management' functions of production function can differ. For example; whereas in turbulence environment, coordination can be a primary function in production function, planning can be primary function in financing function. In other words; in turbulence environment, it is important to consider the priorities of business management functions. Therefore; it needs to be evaluated in detail in terms of the management' action of business' functions in turbulence environment.

In literature review, the answers related to subjects stated above, related to turbulence management which occurs in internal environment of business, related to how these issues need to be solved haven't been run across. The main purpose of the study is to develop an analytic model which considers the issues stated above.

The titles and contents of the chapters after the introductory part of this study are organized as follows: In the second part of the study, a description of the methods and techniques used to solve the problem have been presented. In the method section, the analytical hierarchy process technique used in the study has been explained. Along with that the main steps of the proposed model has been given. In the third part of the study, the results of the study have given in detail. In the fourth part of the study, conclusions have been given in line with the results of the study. 


\section{METHOD}

This study has been made in a business which functions in textile sector. The business which is the unit of analysis has a mid-tier structure which produces ready wear for domestic and abroad markets. In this project, it has been made the analysis of business internal environment at first for which the turbulence management model of business is created and its analysis. The analysis of the internal environment has two main purposes: the first one is that the internal environment components of business which is in the scope of the analysis are determined. The second aim is that the data which will be input for the analysis and evaluation of business for the turbulence management. Hence; in the study, it has been used a question and data acquisition form which includes 64 items to analyze business internal environment. The questions are about getting information related to the basic and supportive functions of business which is in the scope of the study.

That the model which is about business internal environment turbulence management is structured has been made in accordance with the principles of AHP method. AHP is a multiple criteria decision making method which Saaty (1980:1986) developed with a mathematical approach. It gives priority to the components of a hierarchical problem with a range of axioms. In addition; it is calculated the consistency of the comparisons which are made in AHP (Saaty, 1980:1986). In AHP technique, for the solution of a problem, firstly; the components and sub-components of the problem are separated and are hierarchically modelled. The separation is classified by the common characteristics of the components which causes the problem. It is made the pairwise comparison of the components which are classified in AHP and consequently; it is calculated each component's global weights. It is made the pairwise comparisons according to experts or group's evaluation for the calculation of the components' weights. Pairwise comparisons are practiced with the scale which Saaty (1980) developed. In this project, it has been made pairwise comparisons by being used the scale (Table 1) which Saaty (1980) developed. The pairwise comparisons which the model created in this study is required, according to the scale in Table 1 (Yüksel, Dağdeviren and Kabak, 2018), are made in accordance with an expert team which consists of the high-ranking decision-makers of business.

Table 1.The Significance Level in Pairwise Comparison Matrix

\begin{tabular}{lll}
\hline$a_{\mathrm{ij}}$ & Definition & Explanation \\
\hline 1 & Equal importance & Two activity equally contributes to the aim \\
\hline 3 & Weak importance & The activity is relatively preferred if it is compared with the other \\
\hline 5 & Strong importance & The activity is strongly preferred if it is compared with the other \\
\hline 9 & Very stronger proven importance & The activity is very strongly preferred if it is compared with the other \\
\hline $2,4,6,8$ & Absolute importance & The activity is preferred due to its high degree of reliability \\
\hline
\end{tabular}


If there are inconsistencies in the pairwise comparisons of the components, expert group or person repeats the pairwise comparisons related to the components. In AHP technique, inconsistencies are not allowed in pairwise comparisons. This characteristic of AHP technique provides the data which is input for the problem to be reliable. In this study, the algorithm and mathematical process of the AHP technique are not discussed in detail. The reason is that the algorithm and mathematical statements about the AHP technique have been explained broadly and widely in relevant literature. Thus; the mathematical characteristics of the AHP technique have been discussed in studies about various fields (Byun, 2001;Ananda, \&Herath, 2003; Herath, 2004;Chou, Lee, \&Chung, 2004; Vashishtha, \& Ramachandran, 2006; Gibney, \&Shang, 2007, Ho, 2008).

Considering the information above, this study has been practiced in phases below-mentioned:

- That the turbulence management model of business is created.

- That the turbulence characteristics weightiness of the model are calculated.

- That the weightiness for the internal environment factors are determined.

- $\quad$ That the management functions are evaluated.

- That the common results of the turbulence management model are determined.

\section{FINDINGS (RESULTS)}

In the first phase of the study, the turbulence management model of business has been data which have been acquired in the analysis of internal environment. The first degree of the turbulence management model (Figure 1) includes the aim of the turbulence management based on the internal environment. In the second degree of the model there are characteristics which are determined to define the internal environment turbulence condition of business. In literature, it is seen that it has been used various characteristics to define and determine the turbulence condition (Dess and Beard, 1984; Rosca and Moldoveanu, 2009). In this study, the complexity, changeability and predictability characteristics have been taken as a basis to define the turbulence condition. These three characteristics have been taken as a basis to define the internal environment turbulence condition of business which has been studied.

The third phase of the model includes the factors which includes the internal environment of business within the research. In this study, the content of the internal environment of business has included the functions of business. Accordingly, these are the business functions which includes the internal environment of business within this research:

- Management system

- Supply system

- Production system

- Marketing system

- Financing system

- Human resources system

- Accounting system

- R\&D system 
It is an expectable situation that the business functions have process for actualizing the purposes of business in normal conditions. However; it is not an expectable situation that a business continues its operation all the time and in any case in normal conditions. Based on this idea, in the turbulence conditions which is one of the unusual conditions in this study, business needs managing its functions. Therefore; the fourth phase of the turbulence model includes the functions of the management activities in the turbulence environment.

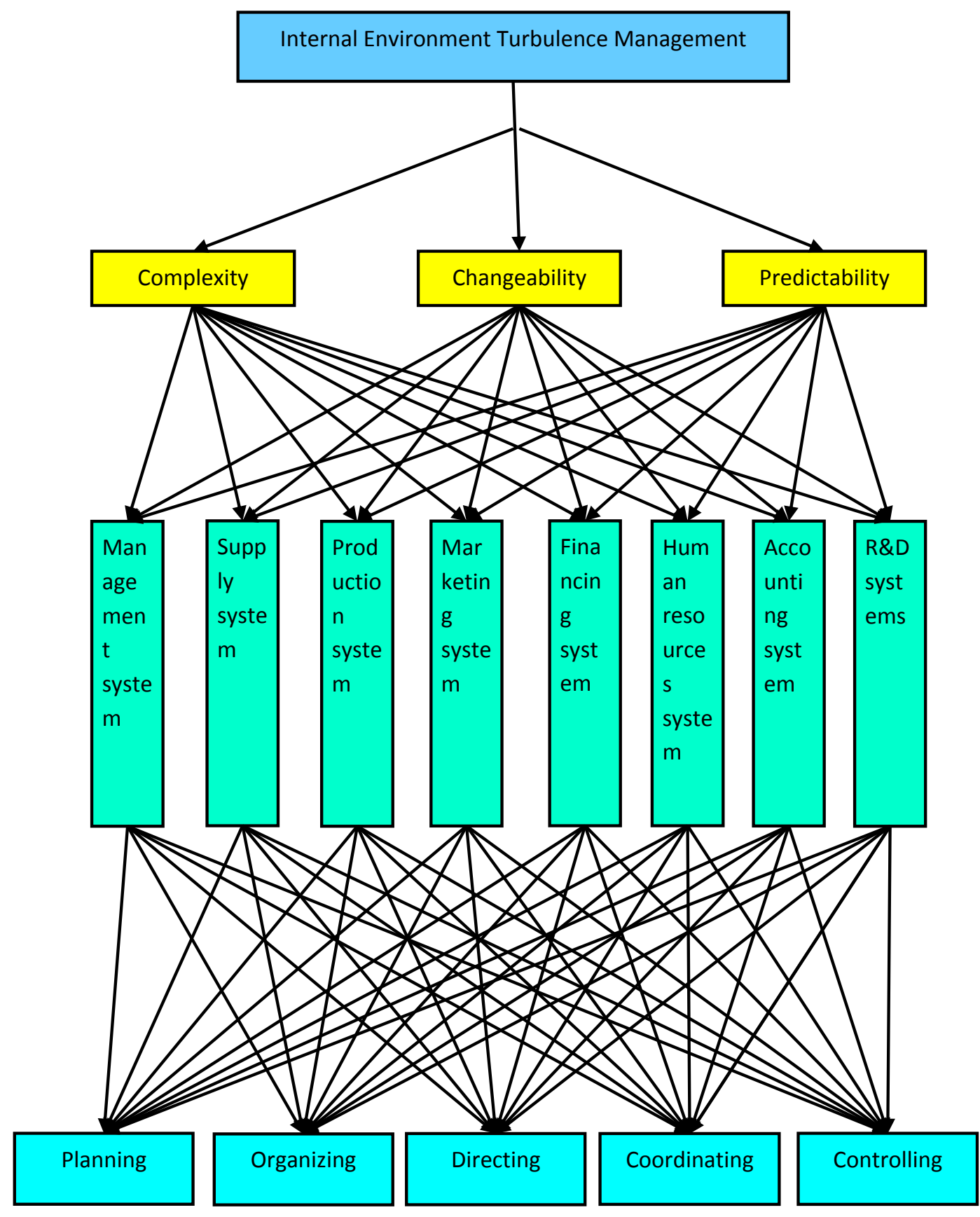

Figure 1. AHP model for internal environment turbulence management 
In the second phase of the study, the turbulence characteristics of the model have been analyzed. The turbulence characteristics in the second phase of the model have been evaluated in accordance with internal environment turbulence management. Therefore; pairwise comparisons have been made. The local weights and consistency rate of pairwise comparison matrix have been calculated in Expert Choice (2000) program. The highest weight is changeability, the second one is predictability and the third high weight is complexity for characteristics of turbulence (Table 2). The rate of consistency ( $C R=0.05)$ for pairwise comparisons is determined in acceptable level.

Table 2. Pairwise comparison matrix for characteristics of turbulence

\begin{tabular}{llllll}
\hline Characteristics of turbulence & CY & CH & PD & $\begin{array}{l}\text { Local } \\
\text { weights }\end{array}$ & CR \\
\cline { 1 - 4 } Complexity (CY) & 1 & $1 / 4$ & $1 / 4$ & 0.109 & 0.05 \\
\cline { 1 - 3 } Changeability (CH) & 1 & 2 & 0.546 & \\
\cline { 1 - 4 } & & & 1 & 0.345 \\
\hline
\end{tabular}

In the third phase of the study, business' functions which are in the third degree of the model and includes business internal environment have been evaluated for characteristics of turbulence. Accordingly, pairwise comparisons of business functions according to the complexity characteristic, the local weights which have been calculated and the rate of consistency have been presented in Table 3. If it is analyzed that business functions are prioritized in complexity, these are functions respectively in the top three degree: Marketing system, financing system and human resources system.

Table 3. Pairwise comparison matrix of business functions according to the complexity

\begin{tabular}{|c|c|c|c|c|c|c|c|c|c|c|}
\hline Business functions & MG & SS & PS & MS & FS & HS & AS & RD & $\begin{array}{l}\text { Local } \\
\text { weights }\end{array}$ & CR \\
\hline Management system (MG) & 1 & 5 & 3 & $1 / 3$ & $1 / 2$ & $1 / 2$ & 3 & 2 & 0.150 & 0.08 \\
\hline Supply system (SS) & & 1 & $1 / 3$ & $1 / 2$ & $1 / 3$ & $1 / 2$ & 2 & 3 & 0.071 & \\
\hline Production system (PS) & & & 1 & 1 & $1 / 2$ & $1 / 3$ & 2 & 3 & 0.110 & \\
\hline Marketing system (MS) & & & & 1 & 2 & 1 & 3 & 4 & 0.204 & \\
\hline Financing system (FS) & & & & & 1 & 2 & 3 & 5 & 0.199 & \\
\hline Human resources system (HS) & & & & & & 1 & 3 & 3 & 0.173 & \\
\hline Accounting system (AS) & & & & & & & 1 & $1 / 2$ & 0.046 & \\
\hline R\&D system (RD) & & & & & & & & 1 & 0.048 & \\
\hline
\end{tabular}


In Table 4, pairwise comparisons of business functions according to the changeability, the local weights which have been calculated and the rate of inconsistency have been discussed. In changeability, in the first place of business functions there is financing system. Marketing system is in the second place and there is supply system in the third place.

Table 4. Pairwise comparison matrix of business functions according to the changeability

\begin{tabular}{|c|c|c|c|c|c|c|c|c|c|c|}
\hline Business functions & MG & SS & PS & MS & FS & HS & AS & RD & $\begin{array}{l}\text { Local } \\
\text { weights }\end{array}$ & CR \\
\hline Management system (MG) & 1 & $1 / 4$ & $1 / 3$ & $1 / 5$ & $1 / 5$ & $1 / 4$ & 3 & 3 & 0.056 & 0.07 \\
\hline Supply system (SS) & & 1 & 2 & $1 / 2$ & $1 / 3$ & 2 & 5 & 7 & 0.173 & \\
\hline Production system (PS) & & & 1 & $1 / 2$ & $1 / 2$ & 3 & 4 & 3 & 0.135 & \\
\hline Marketing system (MS) & & & & 1 & $1 / 2$ & 2 & 3 & 4 & 0.194 & \\
\hline Financing system (FS) & & & & & 1 & 3 & 4 & 5 & 0.271 & \\
\hline Human resources system (HS) & & & & & & 1 & 3 & 2 & 0.095 & \\
\hline Accounting system (AS) & & & & & & & 1 & $1 / 2$ & 0.035 & \\
\hline R\&D system (RD) & & & & & & & & 1 & 0.040 & \\
\hline
\end{tabular}

In Table 5, pairwise comparisons of business' functions according to the predictability, the local weights which have been calculated and the rate of inconsistency have been presented. In predictability factor, if it is analyzed the priorities of business' functions, it has been determined there is financing system in the first place. This is followed by marketing system in the second place and supply system in the third place.

Table 5. Pairwise comparison matrix of business functions according to the predictability

\begin{tabular}{lcccccccccc}
\hline Business functions & MG & SS & PS & MS & FS & HS & AS & RD & $\begin{array}{c}\text { Local } \\
\text { weights }\end{array}$ & CR \\
\hline Management system (MG) & 1 & $1 / 4$ & $1 / 3$ & $1 / 6$ & $1 / 5$ & 4 & 3 & 2 & 0.073 & 0.07 \\
\hline Supply system (SS) & 1 & 2 & $1 / 2$ & $1 / 2$ & 6 & 5 & 6 & 0.193 \\
\hline Production system (PS) & & 1 & $1 / 3$ & $1 / 3$ & 2 & 3 & 3 & 0.106 \\
\hline Marketing system (MS) & & & 1 & $1 / 2$ & 3 & 4 & 3 & 0.221 \\
\hline Financing system (FS) & & & & 1 & 6 & 5 & 4 & 0.280 \\
\hline Human resources system (HS) & & & & & 1 & 2 & 2 & 0.049 \\
\hline Accounting system (AS) & & & & & & 1 & $1 / 2$ & 0.033 \\
\hline R\&D system (RD) & & & & & & & & & & \\
\hline
\end{tabular}


The calculated values have shown that pairwise comparisons of business' functions according to the changeability, predictability and complexity are consistent.

In the fourth phase of the study, it has been evaluated management' functions. Pairwise comparisons for functions of management have been made according to the complexity, changeability, predictability and business' functions respectively.

Considering the complexity characteristic and business' functions, pairwise comparisons of management' functions in the fourth degree of turbulence model, the local weights which have been calculated and the rate of consistency have been shown in Table 6-13.

In Table 6, binary comparisons of management functions based on complexity and management system, calculated weights and consistency ratio have been presented. When Table 6 is examined, planning is 37.3\%, organization is $17.4 \%$, execution is $6.7 \%$, coordination is $24.4 \%$, control is $14.2 \%$. The complexity and consistency ratio of the binary comparison matrix of management functions based on the management system is 0.04 .

Table 6. Pairwise comparison matrix for functions of management according to the complexity and management system

\begin{tabular}{llllllll}
\hline Management functions & PL & OR & DR & CD & CR & $\begin{array}{l}\text { Local } \\
\text { weights }\end{array}$ & CR \\
\cline { 1 - 4 } Planning (PL) & 1 & 3 & 4 & 2 & 2 & 0.373 & 0.04 \\
\hline Organizing (OR) & 1 & 3 & $1 / 2$ & 2 & 0.174 \\
\hline Directing (DR) & & 1 & $1 / 3$ & $1 / 3$ & 0.067 \\
\hline Coordinating (CD) & & & & 1 & 2 & 0.244 \\
\hline Controlling (CR) & & & & & & 1 & 0.142 \\
\hline
\end{tabular}

When weights related to management functions based on complexity and procurement system were examined (Table 7), it was found that planning was $13.2 \%$, organization $7.4 \%$, executive $38.8 \%$, coordination $19.7 \%$, control $20.9 \%$. The duality consistency ratio of management functions based on complexity and supply system was found to be 0.04 . 
Table 7. Pairwise comparison matrix for functions of management according to the complexity and supply system

\begin{tabular}{|c|c|c|c|c|c|c|c|}
\hline Management functions & PL & OR & DR & CD & CR & $\begin{array}{l}\text { Local } \\
\text { weights }\end{array}$ & CR \\
\hline Planning (PL) & 1 & 3 & $1 / 3$ & $1 / 2$ & $1 / 2$ & 0.132 & 0.04 \\
\hline Organizing (OR) & & 1 & $1 / 3$ & $1 / 3$ & $1 / 3$ & 0.074 & \\
\hline Directing (DR) & & & 1 & 3 & 2 & 0.388 & \\
\hline Coordinating (CD) & & & & 1 & 1 & 0.197 & \\
\hline Controlling (CR) & & & & & 1 & 0.209 & \\
\hline
\end{tabular}

In Table 8, binary comparisons of management functions based on complexity and production system and consistency ratio with calculated weights have been presented. As it can be seen from Table 8 , planning is $7.5 \%$, organization is $23.5 \%$, execution is $44.7 \%$, coordination is $12.9 \%$, control is $11.4 \%$. The consistency ratio of the binary comparisons of the matrix is 0.03 .

Table 8. Pairwise comparison matrix for functions of management according to the complexity and production

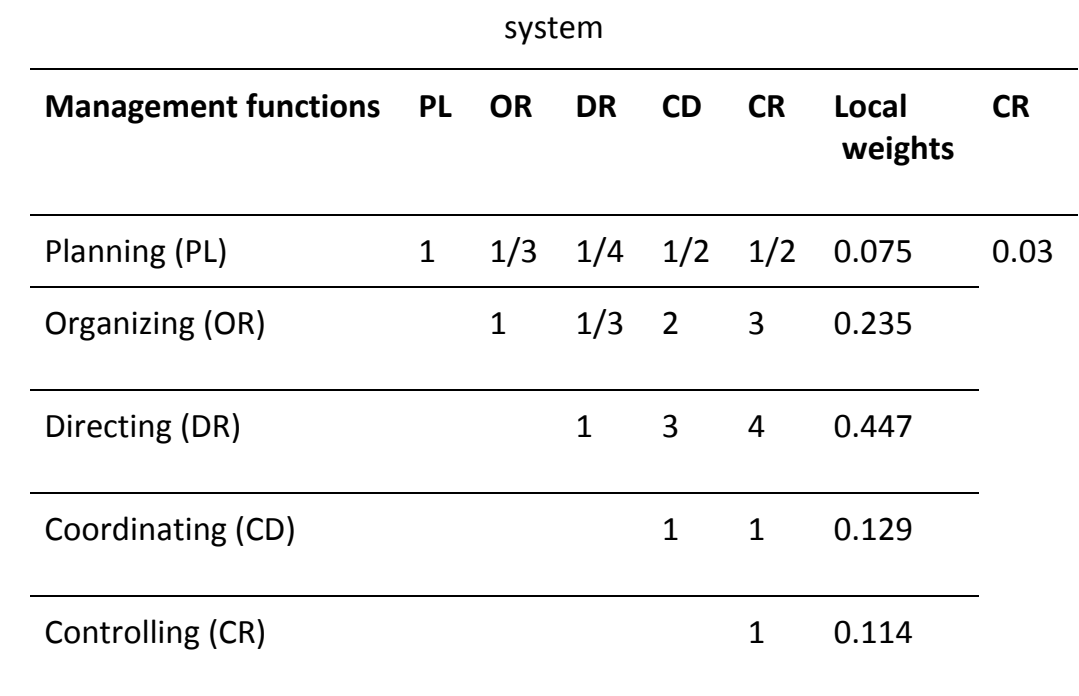

In Table 9, binary comparisons regarding management functions based on complexity and marketing system, local weights and consistency ratio have been given. Planning is $6.8 \%$, organization is $26.8 \%$, executive is $13.3 \%$, coordination is $14.9 \%$, control is $38.1 \%$. The consistency ratio of the comparison matrix for management functions based on complexity and marketing system is 0.03 . 
Table 9. Pairwise comparison matrix for functions of management according to the complexity and marketing system

\begin{tabular}{|c|c|c|c|c|c|c|c|}
\hline Management functions & PL & OR & DR & CD & CR & $\begin{array}{l}\text { Local } \\
\text { weights }\end{array}$ & CR \\
\hline Planning (PL) & 1 & $1 / 3$ & $1 / 2$ & $1 / 3$ & $1 / 5$ & 0.068 & 0.03 \\
\hline Organizing (OR) & & 1 & 2 & 3 & $1 / 2$ & 0.268 & \\
\hline Directing (DR) & & & 1 & 1 & $1 / 3$ & 0.133 & \\
\hline Coordinating (CD) & & & & 1 & $1 / 2$ & 0.149 & \\
\hline Controlling (CR) & & & & & 1 & 0.381 & \\
\hline
\end{tabular}

The comparison matrix for management functions based on complexity and financial system has been presented in Table 10. When weights are examined, planning is $35.4 \%$, organization is $7.8 \%$, execution is $20.7 \%$, coordination is $11.1 \%$, control is $25 \%$. The consistency ratio of the matrix is 0.04 .

Table 10. Pairwise comparison matrix for functions of management according to the complexity and financing system

\begin{tabular}{|c|c|c|c|c|c|c|c|}
\hline Management functions & PL & OR & DR & CD & CR & $\begin{array}{l}\text { Local } \\
\text { weights }\end{array}$ & CR \\
\hline Planning (PL) & 1 & 3 & 2 & 3 & 2 & 0.354 & 0.04 \\
\hline Organizing (OR) & & 1 & $1 / 3$ & $1 / 2$ & $1 / 3$ & 0.078 & \\
\hline Directing (DR) & & & 1 & 3 & $1 / 2$ & 0.207 & \\
\hline Coordinating (CD) & & & & 1 & $1 / 2$ & 0.111 & \\
\hline Controlling (CR) & & & & & 1 & 0.250 & \\
\hline
\end{tabular}

Comparisons of complexity and management functions based on the human resources system have been presented in Table 11. When the table is examined, planning is $36.0 \%$, organization is $17.8 \%$, executive is $8.3 \%$, coordination is $26.4 \%$, control is $11.5 \%$. The binary consistency ratio of management functions based on complexity and human resources system is 0.06 . 
Table 11. Pairwise comparison matrix for functions of management according to the complexity and human resources system

\begin{tabular}{|c|c|c|c|c|c|c|c|}
\hline Management functions & PL & OR & DR & CD & CR & $\begin{array}{l}\text { Local } \\
\text { weights }\end{array}$ & CR \\
\hline Planning (PL) & 1 & 3 & 3 & 2 & 2 & 0.360 & 0.06 \\
\hline Organizing (OR) & & 1 & 2 & $1 / 2$ & 3 & 0.178 & \\
\hline Directing (DR) & & & 1 & $1 / 3$ & $1 / 2$ & 0.083 & \\
\hline Coordinating $(C D)$ & & & & 1 & 3 & 0.264 & \\
\hline Controlling (CR) & & & & & 1 & 0.115 & \\
\hline
\end{tabular}

Comparisons, weights and consistency of management functions based on complexity and accounting system have been given in Table 12. Planning is $35 \%$, organization is $6.2 \%$, execution is $11.8 \%$, coordination is $23.4 \%$, control is $6.5 \%$. The consistency ratio of the matrix is 0.04 .

Table 12. Pairwise comparison matrix for functions of management according to the complexity and accounting

\begin{tabular}{|c|c|c|c|c|c|c|c|}
\hline \multicolumn{8}{|c|}{ system } \\
\hline Management functions & $\mathrm{PL}$ & OR & $\mathrm{DR}$ & $C D$ & $\mathrm{CR}$ & $\begin{array}{l}\text { Local } \\
\text { weights }\end{array}$ & $\mathrm{CR}$ \\
\hline Planning (PL) & 1 & 4 & 3 & 3 & 1 & 0.350 & 0.04 \\
\hline Organizing (OR) & & 1 & $1 / 3$ & $1 / 3$ & $1 / 4$ & 0.062 & \\
\hline Directing (DR) & & & 1 & $1 / 2$ & $1 / 3$ & 0.118 & \\
\hline Coordinating (CD) & & & & 1 & 1 & 0.195 & \\
\hline Controlling (CR) & & & & & 1 & 0.275 & \\
\hline
\end{tabular}

Binary comparison of management functions based on complexity and R \& D system and weights and consistency ratio have been given in Table 13. As it can be seen from the table, planning is $15.7 \%$, organization is $8.4 \%$, execution is $46 \%$, coordination is $23.4 \%$, control is $6.5 \%$. 
Table 13. Pairwise comparison matrix for functions of management according to the complexity and R\&D system

\begin{tabular}{|c|c|c|c|c|c|c|c|}
\hline Management functions & PL & OR & DR & CD & CR & $\begin{array}{l}\text { Local } \\
\text { weights }\end{array}$ & CR \\
\hline Planning (PL) & 1 & 3 & $1 / 3$ & $1 / 2$ & 2 & 0.157 & 0.04 \\
\hline Organizing (OR) & & 1 & $1 / 5$ & $1 / 3$ & 2 & 0.084 & \\
\hline Directing (DR) & & & 1 & 3 & 5 & 0.460 & \\
\hline Coordinating (CD) & & & & 1 & 4 & 0.234 & \\
\hline Controlling (CR) & & & & & 1 & 0.065 & \\
\hline
\end{tabular}

According to changeability characteristic and business' functions, pairwise comparisons of management' functions in the fourth phase of the turbulence model, the local weights which have been calculated and the rate of consistency have been shown in Table 14-21.

The comparison matrix for management functions based on the variability and management system has given in Table 14. When the results are examined, planning is $29.5 \%$, organization is $14.4 \%$, executive is $16.2 \%$, coordination is $10 \%$, control is $29.9 \%$. The consistency ratio of the comparison matrix for management functions based on the variability and management system is 0.06 .

Table 14. Pairwise comparison matrix for functions of management according to the changeability and management system

\begin{tabular}{|c|c|c|c|c|c|c|c|}
\hline Management functions & PL & OR & DR & CD & CR & $\begin{array}{l}\text { Local } \\
\text { weights }\end{array}$ & CR \\
\hline Planning (PL) & 1 & 3 & 2 & 2 & 1 & 0.295 & 0.06 \\
\hline Organizing (OR) & & 1 & 1 & 2 & $1 / 2$ & 0.144 & \\
\hline Directing (DR) & & & 1 & 3 & $1 / 3$ & 0.162 & \\
\hline Coordinating (CD) & & & & 1 & $1 / 2$ & 0.100 & \\
\hline Controlling (CR) & & & & & 1 & 0.299 & \\
\hline
\end{tabular}

The comparison matrix for management functions based on variability and procurement system has been given in Table 15. When weights are examined, planning is $15 \%$, organization is $7.2 \%$, execution is $28.5 \%$, coordination is $40 \%$, control is $9.3 \%$. The consistency ratio of the comparison matrix for management functions based on the variability and supply system is 0.04 . 
Table 15. Pairwise comparison matrix for functions of management according to the changeability and supply system

\begin{tabular}{|c|c|c|c|c|c|c|c|}
\hline Management functions & PL & OR & DR & CD & CR & $\begin{array}{l}\text { Local } \\
\text { weights }\end{array}$ & CR \\
\hline Planning (PL) & 1 & 3 & $1 / 3$ & $1 / 3$ & 2 & 0.150 & 0.04 \\
\hline Organizing (OR) & & 1 & $1 / 5$ & $1 / 4$ & 1 & 0.072 & \\
\hline Directing (DR) & & & 1 & $1 / 2$ & 2 & 0.285 & \\
\hline Coordinating $(C D)$ & & & & 1 & 4 & 0.400 & \\
\hline Controlling (CR) & & & & & 1 & 0.093 & \\
\hline
\end{tabular}

In Table 16, binary comparisons of variability and management functions based on production system, local weights and consistency ratio have been given. Based on the results, planning is $32 \%$, organization is $13.6 \%$, executive is $26.9 \%$, coordination is $14.1 \%$, control is $13.4 \%$. The consistency ratio of the matrix is 0.06 .

Table 16. Pairwise comparison matrix for functions of management according to the changeability and production system

\begin{tabular}{|c|c|c|c|c|c|c|c|}
\hline Management functions & PL & OR & DR & CD & CR & $\begin{array}{l}\text { Local } \\
\text { weights }\end{array}$ & CR \\
\hline Planning (PL) & 1 & 3 & 1 & 3 & 2 & 0.320 & 0.06 \\
\hline Organizing (OR) & & 1 & 1 & $1 / 2$ & 1 & 0.136 & \\
\hline Directing (DR) & & & 1 & 3 & 2 & 0.269 & \\
\hline Coordinating (CD) & & & & 1 & 1 & 0.141 & \\
\hline Controlling (CR) & & & & & 1 & 0.134 & \\
\hline
\end{tabular}

The comparison matrix for management functions based on the variability and marketing system has been shown in Table 17. When the results are examined, planning is $9.8 \%$, organization is $16.3 \%$, executive is $37.1 \%$, coordination is $30.2 \%$, control is $6.6 \%$. The consistency ratio of the binary comparison matrix is 0.04 . 
Table 17. Pairwise comparison matrix for functions of management according to the changeability and marketing system

\begin{tabular}{|c|c|c|c|c|c|c|c|}
\hline Management functions & PL & OR & DR & CD & CR & $\begin{array}{l}\text { Local } \\
\text { weights }\end{array}$ & CR \\
\hline Planning (PL) & 1 & $1 / 2$ & $1 / 3$ & $1 / 4$ & 2 & 0.098 & 0.04 \\
\hline Organizing (OR) & & 1 & $1 / 2$ & $1 / 3$ & 3 & 0.163 & \\
\hline Directing (DR) & & & 1 & 2 & 5 & 0.371 & \\
\hline Coordinating $(C D)$ & & & & 1 & 3 & 0.302 & \\
\hline Controlling (CR) & & & & & 1 & 0.066 & \\
\hline
\end{tabular}

The comparison matrix for management functions based on the variability and financial system is given in Table 18. Planning function is $9.6 \%$, organization is $5.4 \%$, execution is $16.5 \%$, coordination is $35.4 \%$, control is $33 \%$. The consistency ratio of the comparison matrix for management functions based on the variability and financial system is 0.04 .

Table 18. Pairwise comparison matrix for functions of management according to the changeability and financing system

\begin{tabular}{|c|c|c|c|c|c|c|c|}
\hline Management functions & PL & OR & DR & CD & CR & $\begin{array}{l}\text { Local } \\
\text { weights }\end{array}$ & CR \\
\hline Planning (PL) & 1 & 3 & $1 / 2$ & $1 / 4$ & $1 / 5$ & 0.096 & 0.04 \\
\hline Organizing (OR) & & 1 & $1 / 4$ & $1 / 5$ & $1 / 4$ & 0.054 & \\
\hline Directing (DR) & & & 1 & $1 / 3$ & $1 / 2$ & 0.165 & \\
\hline Coordinating (CD) & & & & 1 & 1 & 0.354 & \\
\hline Controlling (CR) & & & & & 1 & 0.330 & \\
\hline
\end{tabular}

The comparison matrix for variability and management functions based on human resources system has been presented in Table 19. When the results are examined, planning is $15.6 \%$, organization is $5.2 \%$, executive is $10.5 \%$, coordination is $25.7 \%$, control is $43.1 \%$. The comparison consistency ratio of the matrix is 0.02 . 
Table 19. Pairwise comparison matrix for functions of management according to the changeability and human resources system

\begin{tabular}{|c|c|c|c|c|c|c|c|}
\hline Management functions & PL & OR & DR & CD & CR & $\begin{array}{l}\text { Local } \\
\text { weights }\end{array}$ & CR \\
\hline Planning (PL) & 1 & 3 & 2 & $1 / 2$ & $1 / 3$ & 0.156 & 0.02 \\
\hline Organizing (OR) & & 1 & $1 / 3$ & $1 / 4$ & $1 / 7$ & 0.052 & \\
\hline Directing (DR) & & & 1 & $1 / 3$ & $1 / 4$ & 0.105 & \\
\hline Coordinating $(C D)$ & & & & 1 & $1 / 2$ & 0.257 & \\
\hline Controlling (CR) & & & & & 1 & 0.431 & \\
\hline
\end{tabular}

The comparison matrix for management functions based on the variability and accounting system has been presented in Table 20 . Planning is $15 \%$, organization is $7.4 \%$, executive is $40.2 \%$, coordination is $8.4 \%$, control is $29 \%$. The consistency ratio of the binary comparisons based on the variability and accounting system is 0.03 .

Table 20. Pairwise comparison matrix for functions of management according to the changeability and accounting system

\begin{tabular}{|c|c|c|c|c|c|c|c|}
\hline Management functions & PL & OR & DR & CD & CR & $\begin{array}{l}\text { Local } \\
\text { weights }\end{array}$ & CR \\
\hline Planning (PL) & 1 & 3 & $1 / 3$ & 2 & $1 / 3$ & 0.150 & 0.03 \\
\hline Organizing (OR) & & 1 & $1 / 4$ & 1 & $1 / 4$ & 0.074 & \\
\hline Directing (DR) & & & 1 & 4 & 2 & 0.402 & \\
\hline Coordinating (CD) & & & & 1 & $1 / 3$ & 0.084 & \\
\hline Controlling (CR) & & & & & 1 & 0.290 & \\
\hline
\end{tabular}

The comparison matrix for management functions based on variability and R \& $D$ system has been given in Table 21 . Planning is $20.2 \%$, organization is $9.1 \%$, execution is $46.5 \%$, coordination is $10.8 \%$, control is $13.4 \%$. The consistency ratio of the binary comparison matrix is 0.02 .

Table 21. Pairwise comparison matrix for functions of management according to the changeability and R\&D

\begin{tabular}{|c|c|c|c|c|c|c|c|}
\hline Management functions & PL & OR & DR & CD & CR & $\begin{array}{l}\text { Local } \\
\text { weights }\end{array}$ & CR \\
\hline Planning (PL) & 1 & 2 & $1 / 3$ & 2 & 2 & 0.202 & 0.02 \\
\hline Organizing (OR) & & 1 & $1 / 5$ & 1 & $1 / 2$ & 0.091 & \\
\hline Directing (DR) & & & 1 & 4 & 3 & 0.465 & \\
\hline Coordinating (CD) & & & & 1 & 1 & 0.108 & \\
\hline Controlling (CR) & & & & & 1 & 0.134 & \\
\hline
\end{tabular}


According to the predictability and business' functions, pairwise comparisons of management' functions in the fourth degree of the turbulence model, the local weights which have been calculated and the rate of consistency have been given in Table 22-29.

The comparison matrix for management functions based on predictability and management system has been presented in Table 22. Planning is $7.3 \%$, organization is $38 \%$, executive is $10.7 \%$, coordination is $24 \%$, control is 20.1\%. The binary comparison consistency ratio of management functions based on predictability and management system is 0.06 .

Table 22. Pairwise comparison matrix for functions of management according to the complexity and management system

\begin{tabular}{|c|c|c|c|c|c|c|c|}
\hline Management functions & PL & OR & DR & CD & CR & $\begin{array}{l}\text { Local } \\
\text { weights }\end{array}$ & CR \\
\hline Planning (PL) & 1 & $1 / 3$ & $1 / 2$ & $1 / 3$ & $1 / 4$ & 0.073 & 0.06 \\
\hline Organizing (OR) & & 1 & 3 & 2 & 3 & 0.380 & \\
\hline Directing (DR) & & & 1 & $1 / 2$ & $1 / 3$ & 0.107 & \\
\hline Coordinating (CD) & & & & 1 & 2 & 0.240 & \\
\hline Controlling (CR) & & & & & 1 & 0.201 & \\
\hline
\end{tabular}

The comparison matrix for predictability and management functions based on the supply system has been presented in Table 23. When the results are examined, planning is $10.1 \%$, organization is $15.3 \%$, execution is $22 \%$ and control is $5.3 \%$. The consistency ratio of binary comparisons is 0.05 .

Table 23. Pairwise comparison matrix for functions of management according to the complexity and supply

\begin{tabular}{|c|c|c|c|c|c|c|c|}
\hline \multicolumn{8}{|c|}{ system } \\
\hline Management functions & PL & OR & DR & CD & CR & $\begin{array}{l}\text { Local } \\
\text { weights }\end{array}$ & CR \\
\hline Planning (PL) & 1 & $1 / 2$ & $1 / 3$ & $1 / 4$ & 3 & 0.101 & 0.05 \\
\hline Organizing (OR) & & 1 & $1 / 2$ & $1 / 4$ & 4 & 0.153 & \\
\hline Directing (DR) & & & 1 & $1 / 3$ & 3 & 0.220 & \\
\hline Coordinating (CD) & & & & 1 & 6 & 0.473 & \\
\hline Controlling (CR) & & & & & 1 & 0.053 & \\
\hline
\end{tabular}

The comparison matrix for predictability and management functions based on the production system has been presented in Table 24. When weights of management functions are examined, planning is $18.3 \%$, organization 
is $7.3 \%$, executive is $16 \%$, coordination is $28.3 \%$, control is $30.1 \%$. The consistency ratio of the binary comparison matrix is 0.06 .

Table 24. Pairwise comparison matrix for functions of management according to the complexity and production system

\begin{tabular}{|c|c|c|c|c|c|c|c|}
\hline Management functions & PL & OR & DR & CD & CR & $\begin{array}{l}\text { Local } \\
\text { weights }\end{array}$ & CR \\
\hline Planning (PL) & 1 & 3 & 2 & $1 / 2$ & $1 / 3$ & 0.183 & 0.06 \\
\hline Organizing (OR) & & 1 & $1 / 2$ & $1 / 3$ & $1 / 4$ & 0.073 & \\
\hline Directing (DR) & & & 1 & $1 / 2$ & 1 & 0.160 & \\
\hline Coordinating (CD) & & & & 1 & 1 & 0.283 & \\
\hline Controlling (CR) & & & & & 1 & 0.301 & \\
\hline
\end{tabular}

Bilateral comparisons of management functions based on predictability and marketing system, weights and consistency ratio have been given in Table 25. When Table 25 is examined, planning is $26.6 \%$, organization is $7.8 \%$, executive is $17.3 \%$, coordination is $12.1 \%$, control is $36.2 \%$. The consistency ratio of the comparison matrix for management functions based on predictability and marketing system is 0.05 .

Table 25. Pairwise comparison matrix for functions of management according to the complexity and marketing system

\begin{tabular}{|c|c|c|c|c|c|c|c|}
\hline Management functions & PL & OR & DR & CD & CR & $\begin{array}{l}\text { Local } \\
\text { weights }\end{array}$ & CR \\
\hline Planning (PL) & 1 & 3 & 2 & 3 & $1 / 2$ & 0.266 & 0.05 \\
\hline Organizing (OR) & & 1 & $1 / 3$ & $1 / 2$ & $1 / 3$ & 0.078 & \\
\hline Directing (DR) & & & 1 & 2 & $1 / 3$ & 0.173 & \\
\hline Coordinating (CD) & & & & 1 & $1 / 2$ & 0.121 & \\
\hline Controlling (CR) & & & & & 1 & 0.362 & \\
\hline
\end{tabular}

The comparison matrix for management functions based on predictability and financial system, local weights and consistency ratio have presented in Table 26. When Table 26 is examined, the weight of planning function is $26.3 \%$, organization is $7.5 \%$, execution is $16.4 \%$, coordination is $13.7 \%$, control is $36.1 \%$. The consistency ratio of the binary comparison matrix is 0.03 . 
Table 26. Pairwise comparison matrix for functions of management according to the complexity and financing system

\begin{tabular}{|c|c|c|c|c|c|c|c|}
\hline Management functions & PL & OR & DR & CD & CR & $\begin{array}{l}\text { Local } \\
\text { weights }\end{array}$ & CR \\
\hline Planning (PL) & 1 & 4 & 2 & 2 & $1 / 2$ & 0.263 & 0.03 \\
\hline Organizing (OR) & & 1 & $1 / 3$ & $1 / 2$ & $1 / 3$ & 0.075 & \\
\hline Directing (DR) & & & 1 & 1 & $1 / 2$ & 0.164 & \\
\hline Coordinating $(C D)$ & & & & 1 & $1 / 3$ & 0.137 & \\
\hline Controlling (CR) & & & & & 1 & 0.361 & \\
\hline
\end{tabular}

Comparisons of predictability and management functions based on the human resources system, local weights and consistency have been given in Tablo 27. When Table 27 is examined, planning is $18.4 \%$, organization is $8.5 \%$, execution is $30.7 \%$, coordination is $26 \%$, control is $16.4 \%$. The consistency ratio of the predictability and the comparison of the management functions based on the human resources system was found to be 0.06

Table 27. Pairwise comparison matrix for functions of management according to the complexity and human resources system

\begin{tabular}{|c|c|c|c|c|c|c|c|}
\hline Management functions & PL & OR & DR & CD & CR & $\begin{array}{l}\text { Local } \\
\text { weights }\end{array}$ & CR \\
\hline Planning (PL) & 1 & 2 & $1 / 2$ & $1 / 2$ & 2 & 0.184 & 0.06 \\
\hline Organizing (OR) & & 1 & $1 / 3$ & $1 / 3$ & $1 / 2$ & 0.085 & \\
\hline Directing (DR) & & & 1 & 2 & 1 & 0.307 & \\
\hline Coordinating (CD) & & & & 1 & 2 & 0.260 & \\
\hline Controlling (CR) & & & & & 1 & 0.164 & \\
\hline
\end{tabular}

When the weights of the comparisons between management functions based on predictability and accounting system given in Table 28 are examined, planning is $14.4 \%$, organization is $6.8 \%$, executive is $10.1 \%$, coordination is $36.7 \%$, control is $32 \%$. The consistency ratio of the binary comparison matrix is 0.04 . 
Table 28. Pairwise comparison matrix for functions of management according to the complexity and accounting system

\begin{tabular}{|c|c|c|c|c|c|c|c|}
\hline Management functions & PL & OR & DR & CD & CR & $\begin{array}{l}\text { Local } \\
\text { weights }\end{array}$ & CR \\
\hline Planning (PL) & 1 & 3 & 2 & $1 / 4$ & $1 / 3$ & 0.144 & 0.04 \\
\hline Organizing (OR) & & 1 & 1 & $1 / 5$ & $1 / 5$ & 0.068 & \\
\hline Directing (DR) & & & 1 & $1 / 3$ & $1 / 2$ & 0.101 & \\
\hline Coordinating (CD) & & & & 1 & 1 & 0.367 & \\
\hline Controlling (CR) & & & & & 1 & 0.320 & \\
\hline
\end{tabular}

The comparison matrix for management functions based on predictability and R \& $D$ system has been presented in Table 29. Planning is $12.5 \%$, organization is $6.2 \%$, execution is $42.7 \%$, coordination is $18.7 \%$, control is $19.9 \%$. The consistency ratio of the binary comparison matrix is 0.04 .

Table 29. Pairwise comparison matrix for functions of management according to the complexity and R\&D

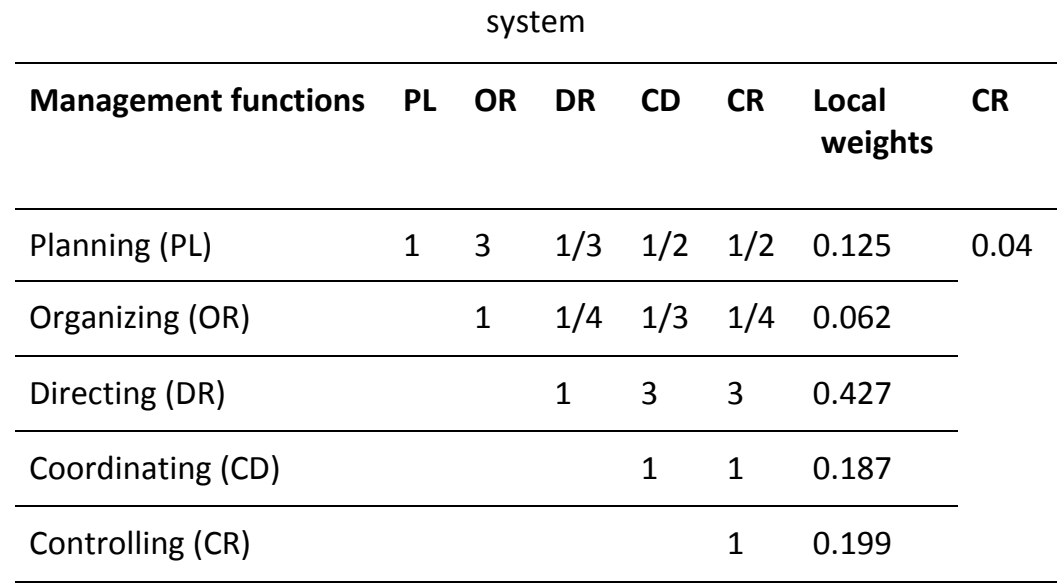

In the final phase of the study, the results of the model have been accounted as a whole. The weights of management' functions which have been calculated by analyzing the turbulence model designed in this study as a whole have been given in Table 30. As it is seen in Table 30, the highest function for the global weights of the turbulence management' functions of business within this research is coordinating function. The second mainly function is controlling and the third one is directing function. The fourth function is planning and the fifth function is organizing function for global weights. 
Table 30. The priorities of functions of turbulence management

\begin{tabular}{cc}
\hline Functions of Management & Global Weights \\
\hline Planning & 0.181 \\
\hline Organizing & 0.109 \\
\hline Directing & 0.225 \\
\hline Coordinating & 0.255 \\
\hline Controlling & 0.229 \\
\hline
\end{tabular}

In Figure 2, the results of sensitivity analysis of each function of turbulence management have been shown. Sensitivity analysis shows how the functions of management change in comparison with each other and also the priorities of management change according to the main and sub-purposes. $Y$-axis in Figure shows the weights of each turbulence criterion and the global weights of turbulence. Accordingly, in order of changeability (CH), predictability (PD), complexity (CY) have been prioritized. In terms of complexity (CY) it has been given priority to the functions of planning, controlling, directing, coordinating and organizing.

Coordinating, directing, controlling, planning and organizing have been given priority in terms of changeability $(\mathrm{CH})$. Controlling, coordinating, planning and organizing have been prioritized in terms of predictability criterion (PD). It is seen that functions of coordinating, controlling, directing, planning and organizing are prior on the general aspect. Management functions seem to be very sensitive to turbulence characteristics. It can be said that the effect of turbulence characteristics on management functions varies based on the types of characteristics.

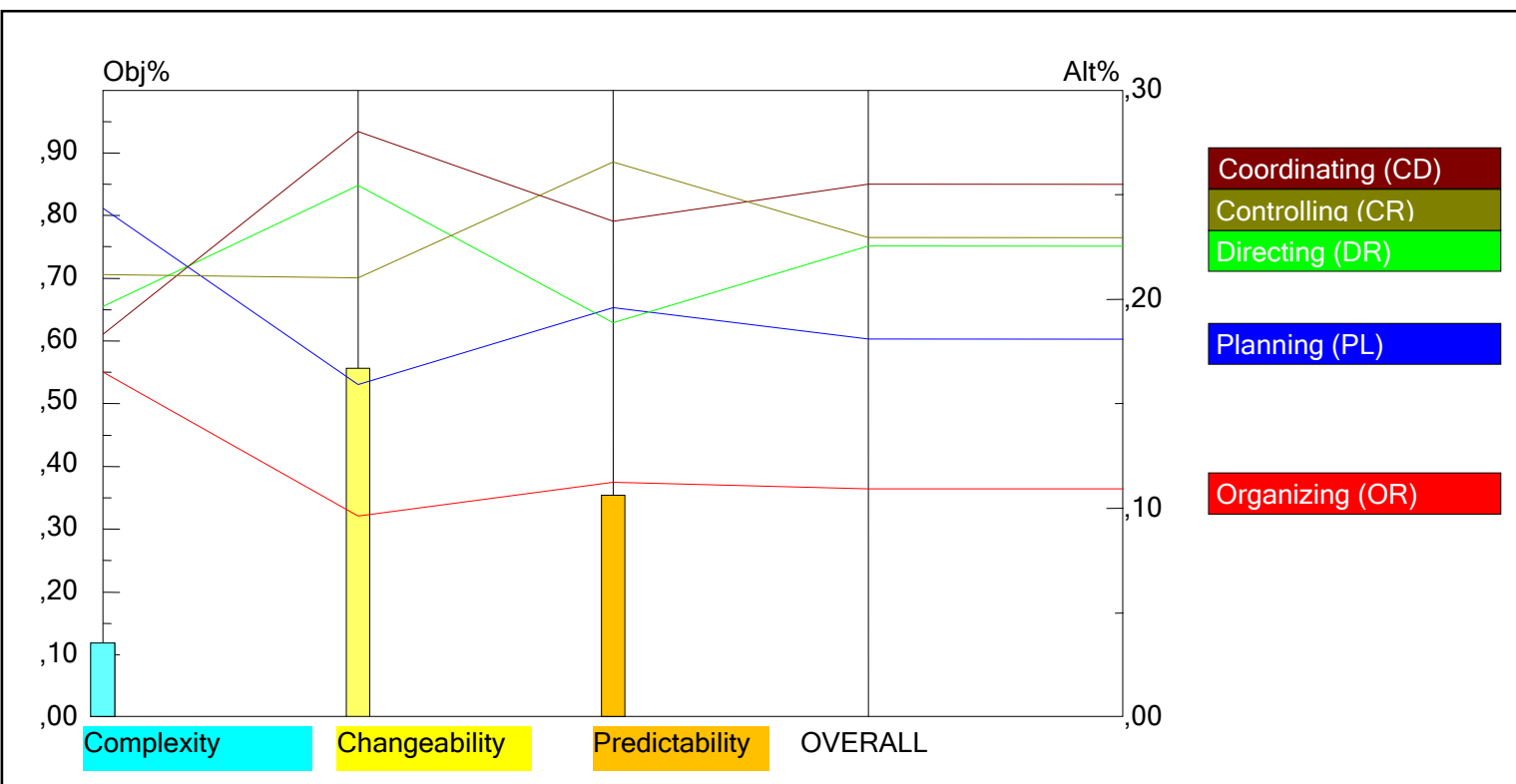

Figure.2. Performance Sensitivity for management functions according to turbulence criteria and overall 


\section{CONCLUSION and DISCUSSION}

It can be said that internal environment which provides actions and functions of business to be actualized are comparatively more stable than external environment of business. However; it is not possible that internal environment of business is completely unchangeable and it can not be thought differently from factors which cause instability. One of the conditions which can arise in internal environment of business which is affected by various factors and conditions is turbulence condition. In this study, it has been analyzed management of turbulence condition which is possible to encounter in internal environment of a business. Turbulence management model which has been created in the study has been analyzed with AHP technique as a result of 312 pairwise comparisons in 24 matrices.

The results of the study have shown that business internal environment turbulence management model can objectively evaluated with AHP technique. Business internal environment turbulence management model which has been analyzed in the study has a multidimensional characteristic. That the model is multidimensional has been found functional in terms of including the factors which constitute internal environment of business. Turbulence management model which has been analyzed in the study has also a holistic characteristic. This characteristic of the model provides sensitivity for characteristics of turbulence, internal environment factors and management functions of business or the change that any change among sub-factors of these can cause in a whole of the model. Thus; it has been provided the model which has been analyzed in the study to represent the whole of business.

The results of internal environment turbulence management model can be evaluated in four degree. Firstly; in the study, it has been obtained detailed and various results in consequence of the analysis of turbulence management model. The first of these is that the weights of creating turbulence in internal environment of complexity, changeability, predictability characteristics in turbulence management model can be determined. This result gives information about business within research is exposed to what turbulence characteristics in what degree. Secondly; another result which the study has reached has determined that each internal environment factor has importance in what degree according to turbulence characteristics. In this way; in the study, the importance of business internal environment factors has been evaluated according to complexity, changeability, predictability characteristics. Knowing the significance level of business internal environment factors against turbulence characteristics is important in terms of management of priorities of decision-makers for business actions. Thirdly; the priorities of last management functions in the final degree of turbulence management model have been determined according to each internal environment factor. This result which is determined in detail is important because it directs management of business functions in the model as each internal environment factor of business. Fourthly; there are results of turbulence management model which are obtained on the global level. When it is analyzed turbulence management model as a whole in the study, it can be determined what the priorities of business in turbulence management in the global level are. When the general results are analyzed, it is determined that coordinating function is important in the first place in 
turbulence management for business within the research. The management function that is important in the second place is controlling. These two management functions are respectively followed by directing, planning and organizing functions. As it is seen, the results of analysis give information about which business requires giving priority to what management functions in turbulence environment.

\section{SUGGESTIONS}

There can be researches that will be made in the future about some issues which are apart from the content and subject of this study. One of the recommended studies can be about the analysis technique which is used in practicing of turbulence management model. In this study, AHP technique has been used. The main reason of this is that the irrelevance assumption has been made between turbulence characteristics, business functions and management functions in turbulence management model recommended related to business within the research. However; such a hypothesis can not be thought all the time and in any case. In other words; probably, it can be relation or interaction between the factors in the model. Therefore; in studies which can be made in the future, analytic network process (ANP), one of the techniques which considers the relation between the factors in the model, can be used. Another study which can be made in the future can be for the factors of turbulence management model. Such a study can be in two ways. Firstly; it can be for the factors which constitutes business internal environment. In this study, business internal environment has been determined based on business functions. In the future studies, business internal environment can be analyzed considering the sources and capabilities of business. Another study can be recommended as an alternative. Alternatives have been identified as management of functions because they have been considered as internal environment business functions within the research. In other words; management functions have been analyzed as alternatives. However; this situation can show differences according to the goals of turbulence model of business which is the subject of analysis. Another study which can be made after this study can be for preventing or minimizing the complexity, changeability, predictability characteristics in internal environment.

\section{REFERENCES}

Ananda, J., \& Herath, G. (2003). The use of Analytic Hierarchy Process to incorporate stakeholder preferences into regional forest planning. Forest policy and economics, 5(1), 13-26.

Bourgeois III, L. J. (1985). Strategic goals, perceived uncertainty, and economic performance in volatile environments. Academy of management journal, 28(3), 548-573.

Boyne, G. A., \& Meier, K. J. (2009). Environmental turbulence, organizational stability, and public service performance. Administration \& Society, 40(8), 799-824.

Byun, D. H. (2001). The AHP approach for selecting an automobile purchase model. Information \& Management, 38(5), 289-297.

Cameron, K. S., Kim, M. U., \& Whetten, D. A. (1987). Organizational effects of decline and turbulence. Administrative Science Quarterly, 222-240. 
Chou, Y., Lee, C., \& Chung, J. (2004). Understanding m-commerce payment systems through the analytic hierarchy process. Journal of Business Research, 57(12), 1423-1430.

Dess, G. G., \& Beard, D. W. (1984). Dimensions of organizational task environments. Administrative science quarterly, 52-73.

Expert Choice. (2000). Expert choice, Analytical hierarchy process (AHP) Software, Version 9.5. Expert Choice. Pittsburgh.

Gibney, R., \& Shang, J. (2007). Decision making in academia: A case of the dean selection process. Mathematical and Computer Modelling, 46(7-8), 1030-1040.

Herath, G. (2004). Incorporating community objectives in improved wetland management: the use of the analytic hierarchy process. Journal of environmental management, 70(3), 263-273.

Ho, W. (2008). Integrated analytic hierarchy process and its applications-A literature review. European Journal of operational research, 186(1), 211-228.

lansiti, M. (1995). Shooting the rapids: Managing product development in turbulent environments. California Management Review, 38(1), 37-58.

Koçel, T. (2018). Işsletme Yöneticiliği. İstanbul: Beta Yayınları.

Kuivalainen, O., Sundqvist, S., Puumalainen, K., \& Cadogan, J. W. (2004). The effect of environmental turbulence and leader characteristics on international performance: are knowledge-based firms different?. Canadian Journal of Administrative Sciences/Revue Canadienne des Sciences de I'Administration, 21(1), 35-50.

Mason, Roger B.(2007). The external environment's effect on management and strategy. Management Decision, 45(1), 10-28.

Melton, E. K. (2017). Testing turbulence: Exploring the determinants of managerial networking. Public Organization Review, 17(1), 19-37.

Papulo, J., \& Papulova, E. (2010). Strategic think in gand strategic approach in small land middle-sized manufacturing firms, Comenius Management Review, 4(1), 25-34.

Power, B., \& Reid, G. C. (2005). Flexibility, firm-specific turbulence and the performance of the long-lived small firm. Review of Industrial Organization, 26(4), 415-443.

Rosca, I., \& Moldoveanu, G. (2009). Management in turbulent conditions. Journal of EconomicComputation and Economic Cybernetics Studies and Research, 2, 5-12.

Saaty, T. L. (1980). The analytic Hierarchy Process.. New York: McGraw-Hill international Book Company

Saaty, T.L., (1986). Axiomatic Foundation of the Analytic Hierarchy Process. Management Science, 32(7), 841855.

Siggelkow, N., \& Rivkin, J. W. (2005). Speed and search: Designing organizations for turbulence and complexity. Organization Science, 16(2), 101-122.

Smart, C., \& Vertinsky, I. (1984). Strategy and the environment: A study of corporate responses to crises. Strategic management journal, 5(3), 199-213. 
Vashishtha, S., \& Ramachandran, M. (2006). Multicriteria evaluation of demand side management (DSM) implementation strategies in the Indian power sector. Energy, 31(12), 2210-2225.

Yüksel, M., Dağdeviren, M.,\& Kabak, M. (2018). An Analysis of the Factors Determining the Effectiveness of Chemistry Education by Using Fishbone Analysis and AHP-PROMETHEE Techniques. Necatibey Faculty of Education Electronic Journal of Science \& Mathematics Education, 12(1), 442-472. 